\title{
Goodwill Accounting Alternative: Private Versus Non-private Companies
}

\author{
Dahli Gray, DBA, CPA, CGMA, CMA, CFE (Corresponding author) \\ Professor, Graduate School Division, Keiser University \\ 1900 W. Commercial Blvd., Fort Lauderdale, FL 33309, USA \\ Tel: 1-443-465-4559Ｅ-mail: DGray@KeiserUniversity.edu
}

\author{
Monica Jorge \\ Staff Auditor with Cherry Bekaert LLP \\ 14170 SW 84th St. Apt. 206 f, Miami, FL 33183, USA \\ Tel: 1-786-344-8149Ｅ-mail: MJorge@cbh.com \\ Laura Rodriguez \\ Accounting and Finance Coordinator, IBOPE Media \\ 3191 Coral Way \#1000, Miami, FL 33145, USA \\ Tel: 1-786-223-0888Ｅ-mail: LMRodriguez@ibopemedia.com
}

Received: September 22, 2015 Accepted: October 15, 2015 Published: October 16, 2015

doi:10.5296/jsss.v3i1.8433

URL: http://dx.doi.org/10.5296/jsss.v3i1.8433

\begin{abstract}
This article examines the accounting change effective after December 15, 2015 and illustrates the Goodwill Accounting Alternative available to private companies as introduced by the Financial Accounting Standards Board (FASB) Accounting Standards Update (ASU) 2014-18 Business Combinations (Topic 805) Accounting for Identifiable Intangible Assets in a Business Combination - a consensus of the Private Company Council (PCC). The measurement and reporting results of private companies are compared with those of public
\end{abstract}


business entities and not-for-profit entities (i.e., non-private companies) for the same in-scope transactions (i.e., acquisitions, assessing fair value under the equity method, and reorganizations). If a private company adopts the FASB ASU 2014-18, then it must also adopt the FASB ASU 2014-02 Intangibles-Goodwill and Other (Topic 350) Accounting for Goodwill-a consensus of the PCC. This results in the private company amortizing goodwill over 10 or fewer years using the straight-line method. Non-private companies use goodwill impairment testing involving fair value measurements. The illustration presented includes a comparison of the initial and subsequent period measurement and reporting requirements and results and indicates that financial accounting choice can result in a significant monetary difference in the total reported owners' equity.

Keywords: Accounting, Goodwill, FASB, Private Company Council, Impairment

\section{Introduction}

The Financial Accounting Standards Board (FASB) Accounting Standards Codification (ASC) glossary defines goodwill as "an asset representing the future economic benefits arising from other assets acquired in a business combination or an acquisition by a not-for-profit entity that are not individually identified and separately recognized." The "Goodwill Accounting Alternative" provides private companies the option to include the following in goodwill: "(1) customer-related intangible assets unless they are capable of being sold or licensed independently from the other assets of the business and (2) noncompetition agreements" (FASB ASU 2014-18). PricewaterhouseCoopers (PWC) summarized these as follows (PWC, 2015):

"Customer-related intangible assets that would not be recognized under the new guidance include non-transferable customer contracts (regardless of their duration, cancellability, or other terms) and non-transferable customer relationships (with or without outstanding contracts). Examples of customer-related intangible assets that would continue to be separately recognized include customer lists and information (e.g., contact information that is capable of being bought and sold), mortgage servicing rights, commodity supply contracts, and core deposits."

Public business entities and not-for-profit (NFP) entities (i.e., non-private companies) must measure and report these two categories of assets separate from goodwill. Non-private companies have three accounts to manage. However, the fact that the non-private companies may have more accounts to oversee and manage is not an important point compared to the other issues in this area. The effort is in the initial and subsequent measurement of these categories of intangible assets. Private companies that elect to use the Goodwill Accounting Alternative combine all three accounting categories into one goodwill account.

Non-private companies must test all three accounting categories for impairment and/or otherwise adjust them to the lower of fair value or book value. For these companies, "Goodwill shall not be amortized. Instead, goodwill shall be tested for impairment" (FASB ASC 350-20-35).

The measuring and testing process for impairment testing has been viewed as complex and thereby costly. Private companies can elect to avoid the complexity of impairment testing 
with the associated costs by adopting the Goodwill Accounting Alternative. However, they cannot avoid the impairment process completely. Testing must occur whenever there is a triggering event.

If a private company adopts the FASB 2014-18, then it must also adopt FASB ASU 2014-02. This mandates that the private company amortize goodwill using the straight-line method (with no salvage or residual value) over 10 or fewer years. This choice is considered much less complex than testing for impairment. Decreased complexity is thought to decrease cost as it takes less time to apply the measurement process. Time used to account for goodwill is time taken away from generating revenue.

\section{Illustration}

The following illustration holds all variables constant except for goodwill, customer-related intangibles, and noncompetition agreements to highlight the potential impact of selecting the Goodwill Accounting Alternative rather than testing for impairment of goodwill. The federal tax requirement to amortize goodwill and the related intangible accounts over a 15 -year period is held constant, as it is the same whether the Goodwill Accounting Alternative or impairment testing is used for financial accounting. Emerging deferred tax assets and/or liabilities are not addressed in this illustration. The Non-private Company and Private Company are of equivalent size as the Goodwill Accounting Alternative option is not a function of company size but of whether a company is Private or Non-private. Table 1 presents the balance sheets for the two companies as of the first day after the acquisition transaction that resulted in goodwill being recognized.

Table 1. Comparative balance sheets of a non-private and a private company-Post-acquisition for year 1 day 1

\begin{tabular}{|c|c|c|c|}
\hline \multicolumn{2}{|c|}{$\begin{array}{l}\text { Non-private company balance } \\
\text { sheet-Post-acquisition year } 1 \text { day } 1\end{array}$} & \multicolumn{2}{|c|}{$\begin{array}{l}\text { Private company balance } \\
\text { sheet-Post-acquisition year } 1 \text { day } 1\end{array}$} \\
\hline $\begin{array}{l}\text { Assets other than goodwill, } \\
\text { customer-related intangibles, } \\
\text { and noncompetition } \\
\text { agreements }\end{array}$ & $\$ 781000000$ & Assets other than goodwill & $\$ 781000000$ \\
\hline Goodwill & 4000000 & Goodwill & 5000000 \\
\hline Customer-related intangibles & 600000 & & \\
\hline Noncompetition agreements & 400000 & & \\
\hline Total assets & $\$ 786000000$ & Total assets & $\$ 786000000$ \\
\hline Liabilities & $\$ 360000000$ & Liabilities & $\$ 360000000$ \\
\hline Owners' equity & 426000000 & Owners' equity & 426000000 \\
\hline $\begin{array}{l}\text { Total liabilities and owners' } \\
\text { equity }\end{array}$ & $\$ 786000000$ & $\begin{array}{l}\text { Total liabilities and owners' } \\
\text { equity }\end{array}$ & $\$ 786000000$ \\
\hline
\end{tabular}




\section{Macrothink}

Table 2 presents the comparative income statements for the two companies for one year of operating results. It is assumed for illustration purposes that the income results are the same for each of the 10 years. This helps isolate the reported difference of just the results with and without the Goodwill Accounting Alternative being elected.

Table 2. Comparative income statements of a non-private and a private company-Post-acquisition for 1 year assuming the same results each year for 10 years

\begin{tabular}{llll}
\hline $\begin{array}{l}\text { Non-private company income } \\
\text { statement-Post-acquisition each year for 10 } \\
\text { years }\end{array}$ & $\begin{array}{l}\text { Private company income } \\
\text { statement-Post-acquisition each year for 10 } \\
\text { years }\end{array}$ \\
\hline Revenues & 5000000 & Expenses & $\$ 7000000$ \\
Expenses & 3000 & Goodwill expense (2) & 5000000 \\
Impairment testing expense (1) & $\$ 1997000$ & Pre-tax income & 500000 \\
Pre-tax income & 399400 & Taxes at 20\% & $\$ 1500000$ \\
Taxes at 20\% & $\$ 1597600$ & Net income & 300000 \\
Net income & & & $\$ 1200000$ \\
\hline
\end{tabular}

(1) Impairment testing can result in no charge (AICPA, 2014). For this illustration, the assumption for the impairment testing result was that there was no impairment. Expenses are related to the costs of executing the annual impairment test.

(2) Amortizing goodwill over the maximum period allowed of 10 years (i.e., \$5 000000 divided by 10 years $=\$ 500000$ each year)

Table 3 presents the comparative balance sheets of the Non-private Company and the Private Company after one year. Table 4 presents their comparative balance sheets after 10 years. After 10 years, the goodwill amount will be fully amortized by the Private Company that elected the Goodwill Accounting Alternative. In this illustration, goodwill impairment testing by the Non-private Company resulted in the goodwill amount remaining constant over the entire 10 years. While this might not be the most likely or probable result, it is a possible result that is used in the illustration. 


\section{Macrothink}

Table 3. Comparative balance sheets of a non-private and a private company-Post-acquisition for year 2 day 1

\begin{tabular}{|c|c|c|c|}
\hline \multicolumn{2}{|c|}{$\begin{array}{l}\text { Non-private company balance } \\
\text { sheet-Post-acquisition year } 2 \text { day } 1\end{array}$} & \multicolumn{2}{|c|}{$\begin{array}{l}\text { Private company balance } \\
\text { sheet-Post-acquisition year } 2 \text { day } 1\end{array}$} \\
\hline $\begin{array}{l}\text { Assets other than goodwill, } \\
\text { customer-related intangibles, } \\
\text { and noncompetition } \\
\text { agreements }\end{array}$ & $\$ 782597600$ & Assets other than goodwill & $\$ 782700000$ \\
\hline Goodwill & 4000000 & Goodwill & 4500000 \\
\hline Customer-related intangibles & 600000 & & \\
\hline Noncompetition agreements & 400000 & & \\
\hline Total assets & $\$ 787597600$ & Total assets & $\$ 787200000$ \\
\hline Liabilities & $\$ 360000000$ & Liabilities & $\$ 360000000$ \\
\hline Owners' equity & 427597600 & Owners' equity & 427200000 \\
\hline $\begin{array}{l}\text { Total liabilities and owners' } \\
\text { equity }\end{array}$ & $\$ 787597600$ & $\begin{array}{l}\text { Total liabilities and owners' } \\
\text { equity }\end{array}$ & $\$ 787200000$ \\
\hline
\end{tabular}

Assuming that either the economy is relatively stable or the companies are able to adjust for any instability over the 10-year period used in the illustration, the fair value has not declined for goodwill, customer-related intangibles, and noncompetition agreements. Each year the accounts must be tested for impairment, which takes time away from revenue-generating activities. The cost (e.g., salary or wages) of that time is allocated to the cost of conducting the impairment testing. The impairment cost would not necessarily be an additional cost to a company; it could just be a reallocation of an employee's and/or manager's time that could be spent generating revenue or addressing other operating activities.

Under the impairment-testing model, goodwill is an asset with an indefinite life. While the initial goodwill recognized at the point of acquiring the other company may have declined in value, the fair value of goodwill does not decline as new goodwill is built through current operational activities (e.g., enhanced customer and/or supplier relationships). Recognizing goodwill outside of a specific transaction such as acquiring another organization at a price greater than the fair value of the parts (e.g., assets) of the organization changes the nature of what constitutes goodwill. This is an interesting topic beyond the scope of this article. 
Table 4. Comparative balance sheets of a non-private and a private company-Post-acquisition for year 11 day 1

\begin{tabular}{|c|c|c|c|}
\hline \multicolumn{2}{|c|}{$\begin{array}{l}\text { Non-private company balance } \\
\text { sheet-Post-acquisition year } 11 \text { day } 1\end{array}$} & \multicolumn{2}{|c|}{$\begin{array}{l}\text { Private company balance } \\
\text { sheet-Post-acquisition year } 11 \text { day } 1\end{array}$} \\
\hline $\begin{array}{l}\text { Assets other than goodwill, } \\
\text { customer-related intangibles, } \\
\text { and noncompetition } \\
\text { agreements }\end{array}$ & $\$ 796976000$ & Assets other than goodwill & $\$ 798000000$ \\
\hline Goodwill & 4000000 & Goodwill & 0 \\
\hline Customer-related intangibles & 600000 & & \\
\hline Noncompetition agreements & 400000 & & \\
\hline Total assets & $\$ 801976000$ & Total assets & $\$ 798000000$ \\
\hline Liabilities & $\$ 360000000$ & Liabilities & $\$ 360000000$ \\
\hline Owners' equity & 441976000 & Owners' equity & 438000000 \\
\hline $\begin{array}{l}\text { Total liabilities and owners' } \\
\text { equity }\end{array}$ & $\$ 801976000$ & $\begin{array}{l}\text { Total liabilities and owners' } \\
\text { equity }\end{array}$ & $\$ 798000000$ \\
\hline
\end{tabular}

After 10 years, when goodwill is fully amortized by the Private Company, the net difference is \$3 976000 (i.e., \$441 976000 minus \$438 000000 in Table 4) between the monetary amount reported for owners' equity by the Non-private Company and that reported by the Private Company. As amortization of goodwill is a non-cash expense, this is not a cash flow difference of $\$ 3976000$ - however, financial ratios can be impacted. In the illustration, the debt to equity ratio is stronger for the Non-private Company than for the Private Company. Sophisticated creditors and investors would recognize the non-cash impact of electing goodwill amortization versus impairment testing. Impairment testing takes more time than amortization but the magnitude of the additional time should decrease as expertise is developed within an organization to apply the required impairment testing process. It is possible that sophisticated investors would exclude these activities in their analyses.

While Tables 1 through 4 illustrate the potential differences in the balance sheet and income statement, Table 5 summarizes the key pros and cons of the Goodwill Accounting Alternative. Table 5 lists having a definite life as a pro and a con of the Goodwill Accounting Alternative. Having a definite life (i.e., 10 or fewer years for financial accounting and 15 years for federal tax accounting) is a pro as it enables easy calculations. However, having a specific definite life might not be a fair representation of the actual life of goodwill. Decades ago, goodwill was to be amortized over 40 years. It is unclear what might have happened to indicate that 10 years is better than 40 years as an amortization period, as the PCC acknowledged that the 10 -year period is arbitrary and was a compromise among alternatives (e.g., 15 years as in the tax code). This debate is beyond the scope of this article. The monetary amount recognized as 


\section{Macrothink}

an expense is predictable under straight-line depreciation, but there is debate whether it is as useful as measurement results when impairment testing is used. The expense amount included in the income statement might be much larger under amortization than under impairment testing. While a sophisticated financial statement user (e.g., an analyst) would probably ignore expense amounts reported relative to goodwill and related intangibles, other users' (e.g., creditors, investors, suppliers, and/or customers) decisions might be impacted.

Comparability of Private and Non-private Companies' financial statements will be compromised when the former use the Goodwill Accounting Alternative and the latter do not. A situation of similar transactions and events being measured and reported differently will arise. Goodwill will be amortized over 10 or fewer years under the Goodwill Accounting Alternative, which is a simpler method than impairment testing, but there will still be a complicating factor in that the federal tax regulations set the amortization period as 15 years. Deferred tax assets and/or liabilities will need to be measured and reported. As the amortization method takes very little time to implement in comparison to the impairment method, there will be more time for revenue generating and other activities under the Goodwill Accounting Alternative. However, goodwill and related intangible accounts will not be reported at fair value, which is considered useful information. 
Table 5. Pros and cons of the Goodwill Accounting Alternative

Pros Cons

Goodwill deemed to have a definite life, Goodwill deemed to have a definite life, which simplifies cost allocation which might not be a fair or accurate representation

Goodwill includes customer-related Decision makers are not provided with intangible assets unless they are capable of adequate valuable detail

being sold or licensed independently from the other assets of the business, simplifying subsequent measurement and reporting

Amortization expense is predictable

Amortization expense could far exceed the expense associated with impairment testing

A company's annual financial statements will Financial statement comparability be comparable to those of other private companies using the Goodwill Accounting Alternative

compromised between companies reporting under the Goodwill Accounting Alternative versus those reporting under the impairment test

Goodwill amortized over 10 years simplifies measurement and reporting

Goodwill amortized over 15 years for tax accounting causes an additional complexity of measuring and reporting deferred tax assets and/or liabilities

Time taken away from revenue generation and other activities to implement impairment testing is avoided

Goodwill with related accounts will not be reported at fair value, which has been thought to be useful information

Private companies that adopt the Goodwill Accounting Alternative must also adopt the FASB ASU 2014-02, which requires amortization instead of impairment testing. The FASB ASU 2014-02 was effective for annual periods beginning after December 15, 2014. This means that some private companies may have already implemented the FASB ASU 2014-02 and only need to decide whether to merge the following accounts into goodwill: "(1) customer-related intangible assets unless they are capable of being sold or licensed independently from the other assets of the business and (2) noncompetition agreements" (FASB ASU 2014-18). The FASB ASU 2014-18 is effective for fiscal years beginning after December 15, 2015 with early application permitted. Private companies that have not yet adopted the FASB ASU 2014-02 must implement it at the same time as they adopt FASB ASU 2014-18. This article is intended to assist readers in deciding whether to adopt FASB ASU 2014-18 based on preferability. "However, an objective basis for determining preferability among alterative accounting principles has not yet been established, so determinations have to be made subjectively" (Illuzzi, 2015). 


\section{Macrothink}

\section{References}

American Institute of Certified Public Accountants (AICPA). (2014). U.S. GAAP Financial Statements---Best practices in presentation and disclosure. AICPA.

Financial Accounting Standards Board (FASB) Accounting Standards Codification (ASC) 350 (ASC 350-20-35). (2015). Intangibles-Goodwill and Other 20 Goodwill 35 Subsequent Measurement. $F A S B$.

Financial Accounting Standards Board (FASB) Accounting Standard Update (ASU) 2014-02 (2014). Intangibles - Goodwill and Other (Topic 350) Accounting for Goodwill—a consensus of the Private Company Council. FASB. Retrieved from http://www.fasb.org/jsp/FASB/Document_C/DocumentPage?cid=1176163744355\&accepted Disclaimer $=$ true

Financial Accounting Standards Board (FASB) Accounting Standard Update (ASU) 2014-18 (2014). Business Combinations (Topic 805) Accounting for Identifiable Intangible Assets in a Business Combination - a consensus of the Private Company Council. FASB. Retrieved from http://www.fasb.org/resources/ccurl/218/786/ASU\%202014-18.pdf

Illuzzi, K. (2015). Preferability and the private company alternatives: How a FASB principle for accounting policy decisions affects election of options developed by the PCC. Journal of Accountancy. 46-48.

PricewaterhouseCoopers (PWC). (2015). FASB provides private companies relief on intangibles. $\quad P W C$. Retrieved from http://www.pwc.com/en_US/us/cfodirect/assets/pdf/in-depth/us2015-02-fasb-provides-private -companies-relief-on-intangibles.pdf

\section{Copyright Disclaimer}

Copyright reserved by the author(s).

This article is an open-access article distributed under the terms and conditions of the Creative Commons Attribution license (http://creativecommons.org/licenses/by/3.0/). 